\title{
Farmer's Perception about Climate Change in Latur and Beed Districts of Maharashtra State, India
}

\author{
S.D. Mundhe*, D.D. Suradkar and V.G. Dhulgand \\ Department of Extension Education College of Agriculture, Latur, Vasantrao Naik \\ Marathwada Krishi Vidyapeeth, Parbhani- 431402 (M.S.) India \\ *Corresponding author:
}

\section{Keywords}

Farmers' perceptions, Climate change, Climate mitigation, Adaptation strategies

\section{Article Info}

Accepted: 20 May 2019 Available Online: 10 June 2019

\section{A B S T R A C T}

The present study was conducted mainly with the objective to study "Farmer's perception about climate change in Marathwada Region." For the study, Latur and Beed district were selected from Marathwada region of Maharashtra state during the years 2018-19. Four talukas viz., Latur and Renapur of Latur District and Kaij and Ambajogai from Beed district were selected randomly and two villages from each talukas were selected randomly. From each village fifteen members were randomly selected constituting the sample size 120. Ex-post-facto research design was used for the study. A number of profile characteristics were selected as independent variables to find out profile of farmers of the study area. It was found that, majority $(39.17 \%)$ of respondents educated up to middle school, (57.50\%) had medium farming experience, 55 per cent medium social participation, 76.67 per cent having farming as their major occupation, 33.33 per cent respondents were marginal farmers, $(66.67 \%)$ reported that well as a main source of irrigation, (79.17\%) medium annual income, $(69.17 \%)$ medium socio-economic status, 63.33 per cent had medium awareness about crop insurance, (66.67\%) medium extension contact, $60.00 \%$ medium innovativeness category and $(55.00 \%)$ medium risk orientation. Findings showed that farmers have fairly high level of perception about climate change and its various dimensions. The results regarding perception of farmer's about climate change shows that, 54.17 per cent of farmers had medium perception, 27.50 per cent farmers had high perception about climate change followed by 18.33 per cent of farmers had low perception level about climate change.

\section{Introduction}

Climate change is one of the biggest environmental challenges in all countries in the world. Climate change refers to any change in climate over time, whether due to natural variability and as a result of human activity (IPCC, 2007). It has become a major concern to society because of its potentially adverse impacts worldwide. Climate change without doubt became the critical environmental issue of present decade. Climate is said to be one of the primary determinant of agriculture productivity. United Nations (UN) as well as several national governments are worried that climate 
change may endanger world food security. Studies have indicated that India is particularly vulnerable to climate change, and is likely to suffer with damages to agriculture productivity, food and water security, human health and cattle populations. Hence, the governments of developing countries are more worried about the adverse impact and its implications. Further, people's livelihoods, especially in rural areas, are dependent on agriculture, and climate change poses a direct and serious threat to the livelihoods of millions of people in India.

Perceptions not only shape knowledge but knowledge also shapes perception. Farmers' perceptions about climate change, therefore, strongly affects how they deal with climate induced risks and uncertainties, and undertake specific measures by coping strategies to mitigate the adverse impact of climate change on agriculture. Farmers' perception is the key to mitigating adverse impact of climate change on agriculture; and recommended that specific interventions targeting the farming community as well as other stakeholders needs to be undertaken to improve their preparedness in dealing with its adverse impact. Consequently, the present study was undertaken to study "Farmers' Perception about Climate Change" in Marathwada region of Maharashtra.

The main objectives include to study the profiles of farmers. And also to determine the perception about climate change among the farmers.

\section{Materials and Methods}

The present study was conducted in Latur and Beed district of Marathwada region from Maharashtra state. In Latur district there are 10 tahsils, out of which two tahsils namely Latur, Renapur were randomly selected and Beed district there are 11 tahsils out of which two tahsils namely Ambajogai and Kaij on the basis "Farmer's perception about climate change in Marathwada Region" From each tahsils 2 villages were randomly selected and from each village 15 farmers were randomly selected to comprise 120 respondents. Ex-post facto research design was used for the study. Data were collected by personally interviewing the respondents with the help of pretested structural schedule. Collected data were tabulated properly. Mean and standard deviation, frequency, percentage, coefficient of correlation methods of statistics were used for interpretation of data.

\section{Results and Discussion}

\section{Personal and socio-economic characteristics of the respondents}

A number of profile characteristics were selected as independent variables to find out profile of farmers of the study area. It was observed from Table 1 that, majority of (39.17\%) respondents belongs to middle school category followed by, 20.84 per cent respondents were found in high school category, 18.33 per cent respondents belongs to College/ Post graduation, 10.00 per cent respondents had education level up to primary school, 9.16 per cent respondents were found under illiterate category, 2.50 per cent of the respondents were found that they can read and write category and none of this belongs to under can read only category. Farming experience wise composition of the study sample reveals that, majority of the respondents $(57.50 \%)$ had 'medium' farming experience category while 22.50 per cent respondents belongs to low farming experience category and 20.00 per cent of respondents were found to be having 'high' level of farming experience. As regards social participation majority $(55.00 \%)$ of the respondents had medium category of social participation, while 24.16 per cent 
respondents had high social participation and 20.84 per cent of them were found in low social participation category. As regard to occupation, majority of respondents $(76.67 \%)$ of them were engaged in farming alone. Nearly 8.33 per cent of the respondents were practicing agriculture along with service as their main occupation whereas, 6.67 per cent were engaged in agriculture along with caste occupation followed by about 5.00 per cent of them were doing agriculture along with labour and 3.33 per cent of them were engaged in agriculture along with business.

Land holding, majority (39.17\%) of the respondents were possessing 1.01 to 2.00 ha of land and belongs to small farmers category while 33.33 per cent of the respondents were possessing up to 1 ha of land and belongs to marginal farmers category, and 16.67 per cent of the respondents belonged to medium farmers category (2.01 to 4 ha) whereas; 10.00 per cent farmers included under semi medium farmers category (4.01 to $10.00 \mathrm{ha}$ ) category and very meagre 00.83 per cent of the respondents had more than 10 ha land holding which comes under big farmer's category. Majority $(66.67 \%)$ of farmers had well as irrigation source followed by, (26.67\%) had borewell as irrigation facility, near about 3.33 per cent farmers had pond as irrigation facility, 2.50 per cent farmers depend upon the canal as source of irrigation, 0.83 per cent of farmer had farm pond as source of irrigation and nobody depends on both river and dam as source of irrigation. As regards annual income majority of farmers (79.17\%) belongs 'medium' annual income followed by high (13.33\%) and low (7.50\%). Majority of the respondents $(69.17 \%)$ reported 'medium' socio-economic status, followed by, $15.83 \%$ 'high' socio-economic status and $15.00 \%$ 'low' socio-economic status. As regards their awareness about crop insurance, $63.33 \%$ had 'medium awareness' followed by $23.34 \%$ having 'high' awareness and $13.33 \%$ farmers had low awareness about crop insurance. Additionally, majority $(66.67 \%)$ of respondents had medium level of extension contact followed by $(19.17 \%)$ and (14.16\%) high and low extension contact respectively. As regards innovativeness was quite interesting as 60.00 per cent of study area farmers were in the medium innovative proneness category, while, 25.00 and 15.00 per cent of them were in high and low innovativeness categories, respectively. Majority $(55.00 \%)$ of the respondents were having medium level of risk orientation, whereas, 28.33 per cent and 16.67 per cent belongs to high and low category respectively.

\section{Perception of farmers about climate change}

Perception understands and interpretation of changes in climate (rainfall, temperature) by farmers based on their prior experience.

It was found that the majority of the farmers had medium level followed by high and low level of perception about climate change parameters such as temperature, rainfall and dry spells in various viz, weather and climate, agriculture, health, animal husbandry and industrial sector. Further, farmers' perception about different dimensions of climate change was also analysed and the results are given in the following Table 2. From Table 2.1 it is concluded that, majority of respondents (96.66\%), as is evident from the above table in weather and climate sector, agree to the statement that there has been change in onset date of monsoon (96.66\%), change in date of withdrawal of monsoon $(95.00 \%)$, very high temperature during summer $(94.16 \%)$, there is uneven rainfall $(93.33 \%)$, number of heavy showers decreased these statements were highly perceived by the farmers $(92.50 \%)$. 
Table.1 Distribution of respondents according to their profile ( $N=120)$

\begin{tabular}{|c|c|c|c|}
\hline Sr. No. & Variable & Frequency $(\mathbf{F})$ & Percentage (\%) \\
\hline \multirow[t]{8}{*}{1.} & \multicolumn{3}{|l|}{ Education } \\
\hline & Illiterate & 11 & 9.16 \\
\hline & Can read only & 00 & 00.00 \\
\hline & Can read and write & 03 & 2.50 \\
\hline & Primary school & 12 & 10.00 \\
\hline & Middle school & 47 & 39.17 \\
\hline & High school & 25 & 20.84 \\
\hline & College level & 22 & 18.33 \\
\hline \multirow[t]{4}{*}{2.} & \multicolumn{3}{|l|}{ Farming Experience } \\
\hline & Low & 27 & 22.50 \\
\hline & Medium & 69 & $\mathbf{5 7 . 5 0}$ \\
\hline & High & 24 & 20.00 \\
\hline \multirow[t]{4}{*}{3.} & \multicolumn{3}{|l|}{ Social Participation } \\
\hline & Low & 25 & 20.84 \\
\hline & Medium & 66 & 55.00 \\
\hline & High & 29 & 24.16 \\
\hline \multirow[t]{6}{*}{4.} & \multicolumn{3}{|l|}{ Occupation } \\
\hline & Labour & 06 & 05.00 \\
\hline & Caste occupation & 08 & 06.67 \\
\hline & Business & 04 & 03.33 \\
\hline & Farming & 92 & 76.67 \\
\hline & Service & 10 & 08.33 \\
\hline \multirow[t]{6}{*}{5.} & \multicolumn{3}{|l|}{ Land Holding } \\
\hline & Marginal & 40 & 33.33 \\
\hline & Small & 47 & 39.17 \\
\hline & Medium & 20 & 16.67 \\
\hline & Semi Medium & 12 & 10.00 \\
\hline & Big & 01 & 00.83 \\
\hline \multirow[t]{8}{*}{6.} & \multicolumn{3}{|l|}{ Irrigation facilities } \\
\hline & River & 00 & 00.00 \\
\hline & Pond & 04 & 03.33 \\
\hline & Well & 80 & 66.67 \\
\hline & Farm pond & 01 & 00.83 \\
\hline & Dam & 00 & 00.00 \\
\hline & Canal & 03 & 02.50 \\
\hline & Bore well & 32 & 26.67 \\
\hline \multirow[t]{4}{*}{7.} & \multicolumn{3}{|l|}{ Annual Income } \\
\hline & Low & 09 & 07.50 \\
\hline & Medium & 95 & 79.17 \\
\hline & High & 16 & 13.33 \\
\hline \multirow[t]{4}{*}{8.} & \multicolumn{3}{|l|}{ Socioeconomic Status } \\
\hline & Low & 18 & 15.00 \\
\hline & Medium & 83 & 69.17 \\
\hline & High & 19 & 15.83 \\
\hline
\end{tabular}




\begin{tabular}{|c|c|c|c|}
\hline \multirow[t]{4}{*}{9.} & \multicolumn{3}{|c|}{ Crop Insurance } \\
\hline & Low & 16 & 13.33 \\
\hline & Medium & 76 & 63.33 \\
\hline & High & 28 & 23.34 \\
\hline \multirow[t]{4}{*}{10.} & \multicolumn{3}{|c|}{ Extension Contact } \\
\hline & Low & 17 & 14.16 \\
\hline & Medium & 80 & 66.67 \\
\hline & High & 23 & 19.17 \\
\hline \multirow[t]{4}{*}{11.} & \multicolumn{3}{|c|}{ Innovativeness } \\
\hline & Low & 18 & 15.00 \\
\hline & Medium & 72 & 60.00 \\
\hline & High & 30 & 25.00 \\
\hline \multirow[t]{4}{*}{12.} & \multicolumn{3}{|c|}{ Risk orientation } \\
\hline & Low & 20 & 16.67 \\
\hline & Medium & 66 & 55.00 \\
\hline & High & 34 & 28.33 \\
\hline
\end{tabular}

Table.2 Perception about climate change among the farmers

Table.2.1 Weather and Climate

\begin{tabular}{|l|l|c|c|c|}
\hline Sr. No. & \multicolumn{1}{|c|}{ Statements } & F & $\%$ & Rank \\
\hline $\mathbf{1 )}$ & Change in onset date of monsoon & 116 & 96.66 & I \\
\hline $\mathbf{2 )}$ & Number of rainy days has decreased & 103 & 85.83 & IX \\
\hline $\mathbf{3 )}$ & There is uneven rainfall & 112 & 93.33 & IV \\
\hline $\mathbf{4 )}$ & Occurrence of more dry spell & 109 & 90.83 & VI \\
\hline $\mathbf{5 )}$ & Number of heavy showers decreased & 111 & 92.50 & V \\
\hline $\mathbf{6 )}$ & Change in date of withdrawal of monsoon & 114 & 95.00 & II \\
\hline $\mathbf{7 )}$ & Very high temperature during summer & 113 & 94.16 & III \\
\hline $\mathbf{8 )}$ & Fluctuation in temperature during winter & 104 & 86.66 & VIII \\
\hline $\mathbf{9 )}$ & Summer season is prolonged & 109 & 90.83 & VI \\
\hline $\mathbf{1 0})$ & Heavy rain affect the unfilled grains in cereal crops & 106 & 88.33 & VII \\
\hline
\end{tabular}

Table.2.2 Agriculture

\begin{tabular}{|l|l|c|c|c|}
\hline Sr. No. & \multicolumn{1}{|c|}{ Statements } & F & \% & Rank \\
\hline $\mathbf{1 )}$ & Cropping pattern changed & 109 & 90.83 & V \\
\hline $\mathbf{2})$ & Increased sunlight causing dropping of flowers in fruit crops & 103 & 85.83 & VII \\
\hline $\mathbf{3 )}$ & Pest attack is increased & 113 & 94.16 & II \\
\hline $\mathbf{4 )}$ & Attack of diseases is increased & 110 & 91.66 & IV \\
\hline $\mathbf{5 )}$ & Number of irrigations is increased & 110 & 91.66 & IV \\
\hline $\mathbf{6 )}$ & Wind speed affects the pollination in fruit crops & 107 & 89.16 & VI \\
\hline $\mathbf{7 )}$ & Production of various crops is reducing & 113 & 94.16 & II \\
\hline $\mathbf{8})$ & Traditional varieties of crops are getting extinct & 112 & 93.33 & III \\
\hline $\mathbf{9 )}$ & Ripening time of crops/ fruits are changed & 113 & 94.16 & II \\
\hline $\mathbf{1 0})$ & Quality of crops decreases & 117 & 97.50 & I \\
\hline
\end{tabular}


Table.2.3 Livestock

\begin{tabular}{|l|l|c|c|c|}
\hline Sr. No. & \multicolumn{1}{|c|}{ Statements } & F & $\%$ & Rank \\
\hline $\mathbf{1 )}$ & Poultry and livestock rearing become difficult & 113 & 94.16 & II \\
\hline $\mathbf{2 )}$ & Most of the animal species getting distinct & 87 & 72.50 & VI \\
\hline $\mathbf{3 )}$ & Scarcity of fodder crops & 108 & 90.00 & III \\
\hline $\mathbf{4 )}$ & Habits of animal/ birds are changing & 104 & 86.66 & IV \\
\hline $\mathbf{5 )}$ & Health of farm animals/ cattle are affected & 103 & 85.83 & V \\
\hline $\mathbf{6}$ & Death rate of livestock is increasing & 115 & 95.83 & I \\
\hline
\end{tabular}

Table.2.4 Health

\begin{tabular}{|l|l|c|c|c|}
\hline Sr. No. & \multicolumn{1}{|c|}{ Statements } & F & $\mathbf{\%}$ & Rank \\
\hline $\mathbf{1 )}$ & Increasing deaths & 115 & 95.83 & II \\
\hline $\mathbf{2})$ & Disease and injuries due to heat waves & 102 & 85.00 & VI \\
\hline $\mathbf{3 )}$ & Increased deaths due to floods, storms and droughts & 112 & 93.33 & IV \\
\hline $\mathbf{4})$ & Increased malnutrition & 109 & 90.83 & V \\
\hline $\mathbf{5 )}$ & Diarrhoea and Malaria Diseases & 112 & 93.33 & IV \\
\hline $\mathbf{6}$ & Heat Mortality & 116 & 96.66 & I \\
\hline $\mathbf{7 )}$ & Nasal Diseases due to Air Pollution & 113 & 94.16 & III \\
\hline
\end{tabular}

Table.2.5 Industry

\begin{tabular}{|l|l|c|c|c|}
\hline Sr. No. & \multicolumn{1}{|c|}{ Statements } & F & \% & Rank \\
\hline 1) & Increasing cost of key raw materials & 112 & 93.33 & I \\
\hline $\mathbf{2})$ & Increased water shortage in processing & 102 & 85.00 & IV \\
\hline $\mathbf{3})$ & Fishing industry affected due to rise in sea level & 105 & 87.50 & III \\
\hline $\mathbf{4})$ & Increasing electricity demands & 111 & 92.50 & II \\
\hline
\end{tabular}

Table.3 Overall distribution of the respondents according to their perception about climate change

\begin{tabular}{|c|c|c|c|}
\hline \multirow{2}{*}{ Sr. No. } & Category & \multicolumn{2}{|c|}{ Respondents (N=120) } \\
\cline { 3 - 4 } & & Frequency & Perception \\
\hline $\mathbf{1 .}$ & Low (Up to 31) & 22 & 18.33 \\
\hline $\mathbf{2 .}$ & Medium (32 to 35) & $\mathbf{6 5}$ & $\mathbf{5 4 . 1 7}$ \\
\hline $\mathbf{3 .}$ & High (36 \& above) & 33 & 27.50 \\
\hline & Total & $\mathbf{1 2 0}$ & $\mathbf{1 0 0 . 0 0}$ \\
\hline
\end{tabular}

Whereas; heavy rain affect the unfilled grains in cereal crops $(90.83 \%)$, fluctuation in temperature during winter $(88.33 \%)$, number of rainy days has decreased $(86.66 \%)$ these statements had perception below 91.00 per cent. Therefore it comes under the less perceived statements about weather and climate change. On the basis of observations related to Climate Change Dimensions it can be concluded that that majority of the respondents have felt that there has been a significant amount of change in various parameter of climate change.

From Table 2.2 it is concluded that, a large majority of respondents (97.50\%), as is 
evident from the above table in weather and climate sector, agree to the statement that there has been that quality of crops decreases, ripening time of crops/ fruits are changed and production of various crops is reducing (94.16\%), Pest attack is increased (94.16\%), traditional varieties of crops are getting extinct $(93.33 \%)$ these statements were highly perceived by the farmers. Whereas; wind speed affects the pollination in fruit crops and number of irrigations is increased (91.66\%), cropping pattern changed (90.83\%), 89.16 per cent respondents agreed that wind speed affects the pollination in fruit crops while $(85.83 \%)$ agreed that increased sunlight causing dropping of flowers in fruit crops.

From Table 2.3 it is concluded that, majority of respondents (95.83\%) agreed that death rate of livestock is increasing, (94.16\%) farmers agreed to statement that poultry and livestock rearing become difficult, (90.00\%) farmers said that there was scarcity of fodder crops these statements were highly perceived by the farmers. Whereas, according to $(86.66 \%)$ respondents habits of animal/ birds are changing, $(85.83 \%)$ farmers said that health of farm animals/ cattle are affected, additionally $(72.50 \%)$ farmers said most of the animal species getting distinct.

From Table 2.4 it is concluded that, the statements majority of $(96.66 \%)$ farmers said that there is high danger of heat Mortality, $(95.83 \%)$ said that increasing deaths due to climate change, $(94.16 \%)$ farmers agreed to the statement nasal diseases due to air pollution, additionally (93.33\%) respondents said that diarrhoea and Malaria diseases and increased deaths due to floods storms and droughts, these statements were highly perceived by the farmers, $(90.83 \%)$ agreed with increased malnutrition and (85.00\%) respondents accepted that disease and injuries causes due to heat waves.
From Table 2.5 it is concluded that, majority of respondents (93.33\%), as is evident from the above table in industrial sector, respondents agreed with statement increasing cost of key raw materials, (92.50\%) increasing electricity demands due to climate change, $(87.50 \%)$ fishing industry affected due to rise in sea level and $(85.00 \%)$ agreed with increasing cost of key raw materials.

Data from the table 3, The results regarding perception of farmer's about climate change shows that, 54.17 per cent of farmers had medium perception, 27.50 per cent farmers had high perception about climate change followed by 18.33 per cent of farmers had low perception level about climate change.

The findings of the study are similar to Onyekuru and Marchant (2017), Chand and Kumar (2018), Grimberget.al (2018).

Majorities of the respondents were having education up to middle school, medium farming experience. Also clearly observed that majority of farmers had farming was main occupation, farmers belong to small land holding category, had well was main source of irrigation and belongs to medium annual income category, had medium category of socioeconomic status and farmers have better knowledge about the crop insurance.

Perception of farmer's about climate change shows that, 54.17 per cent of farmers had medium perception, 27.50 per cent farmers had high perception about climate change followed by 18.33 per cent of farmers had low perception level about climate change.

\section{References}

Chand, S. and D. Kumar, 2018. Farmers' perception on climate change and its management strategies: A Micro Analysis of Rajasthan. Indian Res. J. 
Ext. Edu.18 (3).

Grimberg, B.I., S. Ahmed, C. Ellis, Z. Miller and F. Menalled 2018. Climate Change Perceptions and Observations of Agricultural Stakeholders in the Northern Great Plains, Journal of Sustainability 10 (5), pp: 1687.

Islam S, M. H. Kabir, S. Ali, S. Sultana, M. Mahasin (2019) Farmers' Knowledge on Climate Change Effects in Agriculture Journal of Agricultural Sciences pp: 386-394.

Onyekuru, N.A. and Marchant, R. 2017. Climate change perception, awareness and adaptation decision among forest communities in Nigeria. Agro-Science, 16 (3), pp $51-62$.

Osei, S. 2017. Climate Change Adaptation
Constraints among Smallholder Farmers in Rural Households of Central Region of Ghana. West African Journal of Applied Ecology, 25(2), pp: 31-48.

Sivaraj P., H. Philip and V. Geethalakshmi. 2017. Climate Change Impact on SocioEconomic Status and Communication Pattern of the Paddy Farmers of Tamil Nadu, India International Journal of Current Microbiology and Applied Sciences 6 (6) pp: 550-557.

Uddin, M.N., W. Bokelmann and E.S. Dunn, 2017. Determinants of Farmers Percepti on of Climate Change: A Case Study from the Coastal Region of Bangladesh. American Journal of Climate Change, (6), PP: 151-165.

\section{How to cite this article:}

Mundhe, S.D., D.D. Suradkar and Dhulgand, V.G. 2019. Farmer's Perception about Climate Change in Latur and Beed Districts of Maharashtra State. Int.J.Curr.Microbiol.App.Sci. 8(06): 2754-2761. doi: https://doi.org/10.20546/ijcmas.2019.806.332 